\title{
Molecular differentiation of Salmonella Gallinarum and Salmonella Pullorum by RFLP of flic gene from Brazilian isolates
}

\section{author(s)}

Paiva JB

Cavallini JS

Silva MD

Almeida MA

Ângela $\mathrm{HL}$

Berchieri Junior $A^{*}$

Faculdade de Ciências Agrárias e VeterináriasUNESP. Jaboticabal, SP

Departamento de Patologia Veterinária

Laboratório de Ornitopatologia.

\section{Mail Address}

Angelo Berchieri Junior

FCAV-Unesp

Departamento de Patologia Veterinária

Via de acesso Paulo Donato Castellane, s/n

Bairro Rural

14.884-900. Jaboticabal, SP, Brasil

E-mail: berchier@fcav.unesp.br

\section{Keywords}

FliC gene, differentiation, Salmonella Gallinarum, Salmonella Pullorum.

\section{ABSTRACT}

Although Salmonella Pullorum and Salmonella Gallinarum cause different diseases in poultry, they are very similar. Both are non-motile and present the same somatic antigenic structure. They are differentiated by biochemical tests. Certain atypical strains are very difficult to distinguish. They do not produce the expected results when dulcitol and ornithine descarxboxylase tests are performed. Therefore, additional tests could be helpful. Many studies have chose the part I of the gene that encodes flagellin (flic) to differentiate serotypes. Most Salmonella strains have two structural genes (fliC and fliB) that encode flagellins. Non-motile strains generally present these structural genes, but are not able to build a functional flagellum. It was demonstrated that enzymatic restriction of the amplified fliC gene using Hinp1I enzyme can differentiate SG from SP. In the present study, this method was adopted to analyze 14 SP and 22 SG strains, including some strains with atypical results in biochemical tests assessing the utilization of dulcitol and ornithine. The results showed that all SG strains were broken by the enzyme, whereas the 14 SP strains were not.

\section{INTRODUCTION}

According to Kauffman-White scheme (Grimont \& Weill, 2007), more than 2,500 serovars have been described based on the antigen structure of lipopolysaccharide ( $\mathrm{O}$ antigen) and flagellar proteins $(\mathrm{H})$ (Boyd et al., 1993). However, only a limited set of Salmonella serotypes have been associated with poultry diseases and human salmonellosis. Salmonella enterica serotype Gallinarum (SG) and Salmonella enterica serotype Pullorum (SP) are non-motile host-specific avian pathogens. Salmonella Pullorum causes Pullorum disease, which is mainly characterized by septicemia in young birds, with white diarrhea and mortality (Berchieri Jr. \& Freitas Neto, 2009). In general, adult birds do not show symptoms of the disease and may transmit SP to the progeny. Salmonella Gallinarum causes fowl typhoid, an acute septicemic disease with high mortality and morbidity that affects mostly adult birds, although it is very virulent to birds of any age. Some countries are considered free from SP and SG; however, these are sometimes reported, and are still a matter of concern in the poultry industry (Shivaprasad, 2000).

The differentiation between SP and SG is very important from epidemiological and preventive perspectives. They are very similar, and cannot be distinguished by conventional serological methods. The differentiation basically takes into account their biochemical characteristics. The standard methods take approximately 5 to 7 days, and are very time-consuming and expensive. The main biochemical characteristics assessed are the capacity to use dulcitol by SG, but not by SP, and ornithine decarboxylation by SP, but not by SG. Intermediate 
Paiva JB, Cavallini JS, Silva MD, Almeida MA, Ângela HL, Berchieri Junior $A$ strains with atypical behavior in the dulcitol and ornithine descarboxilase biochemical tests were described by Li et al. (1993). SP and SG atypical strains were isolated in Brazil (Ribeiro et al., 2009).

Lately, biochemical methods have been complemented by DNA-based molecular techniques, because of their sensitivity, specificity, and swiftness. Such methods include restriction fragment length polymorphism (RFLP), which is sometimes associated to PCR (PCR-RFLP), IS200 profiling, ribotyping, pulsefield gel electrophoresis (PFGE), and single-strand conformational polymorphism (SSPC) (Christensen et al., 1992; Olsen et al., 1996; Kwon et al., 2000). Many studies used part I of the gene that encodes flagellin (flic) to differentiate serotypes. Most Salmonella strains have two structural genes (fliC and fliB) that encode flagellins. Non-motile strains generally exhibit these structural genes, but are unable to build up a functional flagellum (Popoff et al., 1992).

The objective of the present study was to differentiate SP and SG isolated in Brazil, including strains with atypical biochemical behavior, by a single method: restriction of the amplified flic gene using Hinp 1 I enzyme.

\section{MATERIAL AND METHODS}

Bacterial strains. The strains used in this study are listed in Table 1. These strains were obtained from the Brazilian governmental laboratories LANAGRO, FIOCRUZ, and Adolfo Lutz Institute.

DNA extraction. Bacterial DNA was prepared as described by Soumet et al. (1994) with modifications. SP and SG strains were inoculated in Luria Bertani (LB) broth (Invitrogen 12780-052) and incubated $37^{\circ} \mathrm{C}$ for $24 \mathrm{~h}$ in shaking incubator (100rpm). One $\mathrm{ml}$ of each culture was centrifuged for $3 \mathrm{~min}$ at $13000 \mathrm{xg}\left(4^{\circ} \mathrm{C}\right)$.the resulting pellets were washed twice in $500 \mu \mathrm{L} 1 \mathrm{X}$ TAE buffer (Tris, Acetic Acid, and EDTA; pH 8.0), and centrifuged at $13000 \mathrm{xg}$ for $3 \min \left(4^{\circ} \mathrm{C}\right)$. The pellet was resuspended in $200 \mu \mathrm{L}$ sterile water, boiled for $8 \mathrm{~min}$, and stored at $-20^{\circ} \mathrm{C}$.

PCR primers. The following two primers were used for the amplification of flagellin gene phase 1: CTGGTGATGACGGTAATGGT (fliCF: 866-885) and CAGAAAGTTTCGCACTCTCG (fliCR: 1063-1044) (Kwon et al., 2000).

Amplification of the flic gene by PCR. A
Molecular differentiation of Salmonella Gallinarum and Salmonella Pullorum by RFLP of fliC gene from Brazilian isolates reaction mixture containing $16.8 \mu \mathrm{L}$ ultra pure water (Gibco), $2 \mu \mathrm{L}$ PCR Buffer 10x, 0.7 $\mu \mathrm{L}$ d-NTP $(2 \mathrm{mM}), 0.8 \mu \mathrm{L}$ $\mathrm{MgCl} 2(50 \mathrm{mM}), 0.5 \mu \mathrm{L}$ of each primer, $0.5 \mu \mathrm{L}$ Taq DNA polymerase, and $3.2 \mu \mathrm{L}$ DNA, was prepared. The thermocycler was programmed with 1 cycle of $94^{\circ} \mathrm{C}$ for $5 \mathrm{~min}, 35$ three-step cycles (denaturation at $94^{\circ} \mathrm{C}$ for $30 \mathrm{~s}$, annealing at $58^{\circ} \mathrm{C}$ for $10 \mathrm{~s}$, extension at $72^{\circ} \mathrm{C}$ for 20s), and a final cycle at $72^{\circ} \mathrm{C}$ for $7 \mathrm{~min}$. The amplicons were analyzed by electrophoresis in $1.5 \%$ agarose gel for $1 \mathrm{~h}$ and $80 \mathrm{~V}$. Product size was compared to the $50 \mathrm{pb}$ ladder (Fermentas SM1211) after ethidium bromide staining.

\begin{tabular}{|c|c|c|c|c|}
\hline Strain $n^{\circ}$ & Isolate designation & Salmonella & ODC & Dulcitol \\
\hline 1 & Fiocruz 31 & Gallinarum & $(-)$ & $(+)$ \\
\hline 2 & Fiocruz 33 & Galinarum & $(-)$ & $(+)$ \\
\hline 3 & Fiocruz 34 & Gallinarum & $(-)$ & $(+)$ \\
\hline 4 & Fiocruz 35 & Gallinarum & $(-)$ & $(+)$ \\
\hline 5 & Fiocruz 36 & Gallinarum & $(-)$ & $(+)$ \\
\hline 6 & Lanagro 10 & Gallinarum & $(-)$ & $(+)$ \\
\hline 7 & Lanagro 15 & Galinarum & $(-)$ & $(+)$ \\
\hline 8 & Lanagro $188-1 \mathrm{C}$ & Gallinarum & $(-)$ & $(+)$ \\
\hline 9 & Lanagro 188-2 & Gallinarum & $(-)$ & $(+)$ \\
\hline 10 & Lanagro ATCC & Gallinarum & $(-)$ & $(+)$ \\
\hline 11 & Unesp 256/87 & Galinarum & $(-)$ & $(+)$ \\
\hline 12 & Unesp 291/90 & Gallinarum & $(-)$ & $(+)$ \\
\hline 13 & Unesp 292/90 & Gallinarum & $(-)$ & $(+)$ \\
\hline 14 & Unesp 293/90 & Gallinarum & $(-)$ & $(+)$ \\
\hline 15 & Unesp 297/91 & Galinarum & $(-)$ & $(+)$ \\
\hline 16 & Unesp Greek & Gallinarum & $(-)$ & $(+)$ \\
\hline 17 & Unesp 5441-6 & Gallinarum & $(-)$ & $(+)$ \\
\hline 18 & Unesp Nanabi & Gallinarum & $(-)$ & $(+)$ \\
\hline 19 & Unesp 7285-b & Gallinarum & $(-)$ & $(+)$ \\
\hline 20 & Unesp Hakim-Leban & Gallinarum & $(-)$ & $(+)$ \\
\hline 21 * & Fiocruz 32 & Gallinarum & $(+)$ & $(+)$ \\
\hline 22 & $449 / 87$ & Pullorum & $(+)$ & $(-)$ \\
\hline 23 & Fiocruz 1 & Pullorum & $(+)$ & $(-)$ \\
\hline 24 & Fiocruz 2 & Pullorum & $(+)$ & $(-)$ \\
\hline 25 & Fiocruz 3 & Pullorum & $(+)$ & $(-)$ \\
\hline 26 & Fiocruz 4 & Pullorum & $(+)$ & $(-)$ \\
\hline 27 & Fiocruz 5 & Pullorum & $(+)$ & $(-)$ \\
\hline 28 & Fiocruz 6 & Pullorum & $(+)$ & $(-)$ \\
\hline 29 & Fiocruz 7 & Pullorum & $(+)$ & $(-)$ \\
\hline 30 & Lanagro 11 & Pullorum & $(+)$ & $(-)$ \\
\hline 31 * & Lanagro 335-28 & Pullorum & $(-)$ & $(-)$ \\
\hline $32 *$ & Lanagro 337-28 & Pullorum & $(-)$ & $(-)$ \\
\hline 33 & Lanagro ATCC & Pullorum & $(+)$ & $(-)$ \\
\hline 34 & Unesp 21 & Pullorum & $(+)$ & $(-)$ \\
\hline 35 & SG9R & Gallinarum & $(-)$ & $(+)$ \\
\hline
\end{tabular}

ODC ornithine decarboxylase; *atypical strains.

PCR-RFLP analysis. Digestion solution was prepared with $5 \mu \mathrm{L}$ of the PCR product, $1 \mu \mathrm{L}$ of Hinp 1 l buffer (10x), $0.1 \mu$ l of Hinp 1 l enzyme, and $3.9 \mu$ l of ultra-pure water (Gibco). After incubation at $37^{\circ} \mathrm{C}$ for $1 \mathrm{~h}$, RFLPs were determined by electrophoresis of the digested DNA in $4 \%$ agarose gel for $4 \mathrm{~h}$ at $40 \mathrm{~V}$. Product size of the products was analyzed in comparison to the 50bp ladder (Fermentas SM1211). 
Paiva JB, Cavallini JS, Silva MD, Almeida MA, Ângela HL, Berchieri Junior A

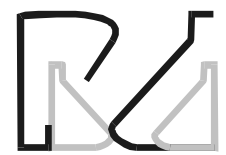

\section{RESULTS}

Amplification of the flic gene. The expected 197 bp fragment of the flic gene was successfully amplified from all the 22 Salmonella Gallinarum strains and 14 Salmonella Pullorum strains tested. Nonspecific pairing was not observed. The amplicons are shown in Figure 1.

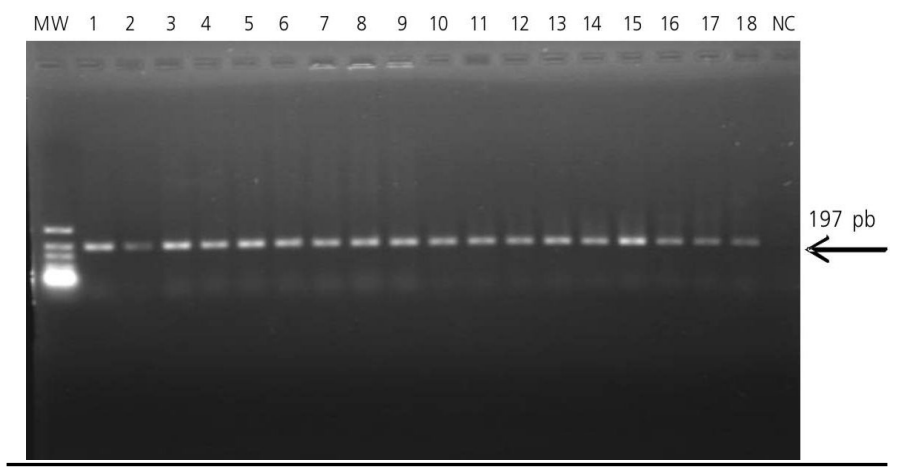

Figure 1. Electrophoresis of fliC gene amplicons from SP and SG samples. MW Molecular weight marker 50bp DNA ladder. SP samples (lanes 1 to 9); SG samples (lanes 10 to 18). NC negative control (ultra pure water)

PCR-RFLP analysis. Twenty-two SG strains and 14 SP strains were analyzed. Digestion of SG amplicons with Hinp 1 I yielded two bands, of 115 and 82 bp, while no change in SP amplicons was observed, since no digestion occurred (Figure 2).

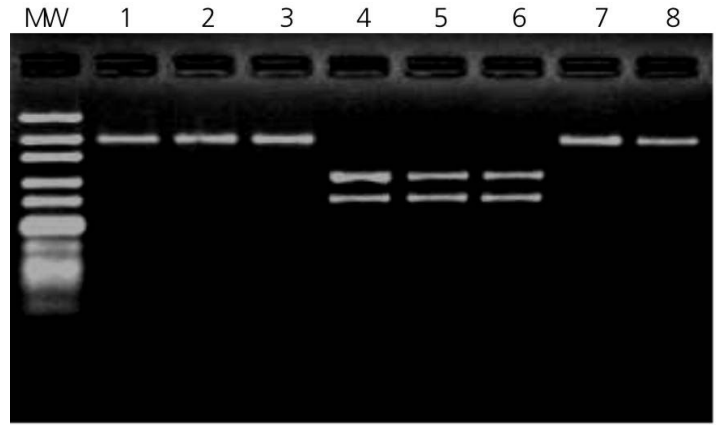

Figure 2. Eletrophoretic analysis of the fliC gene after enzymatic treatment with Hinp I1 restriction enzyme. MW Molecular weight marker 50bp DNA ladder; lanes 1, 2, and 3: digestion product of SP samples; lanes 4, 5, and 6: restriction fragments of the flic gene from SG samples; lane 7: P amplicons not submitted to enzymatic restriction (SP positive control); lane 8: SG amplicons not submitted to digestion (SG positive control).

\section{DISCUSSION AND CONCLUSIONS}

Salmonella Gallinarum and Salmonella Pullorum are non-motile pathogens that infect poultry and other galliform birds (Barrow et al., 1994; Shivaprasad, 2000).
Molecular differentiation of Salmonella Gallinarum and Salmonella Pullorum by RFLP of fliC gene from Brazilian isolates

Salmonella Gallinarum is responsible for fowl typhoid, and Salmonella Pullorum causes pullorosis, which is characterized by white diarrhea in chicks (Pomeroy, 1984). SG, found mostly in adult birds, can also affect young birds. Salmonella Pullorum may infect older chickens, causing symptoms similar to those observed in fowl typhoid (Wray et al., 1996). Therefore, the proper identification of both Salmonella serovars is very important from the epidemiological and control standpoints. The differentiation between SG and SP is based on biochemical characteristics (Cox \& Willians, 1976); Ewing, 1986). These serovars cannot be distinguished by conventional serological methods because they have very similar antigenic O-factors. Biochemical methods are currently complemented by DNA-based molecular techniques. Most Salmonella strains exhibit two structural genes (fliC and fliB) that encode flagellins. Only of these structural genes is expressed in the bacterium at a time. Non-motile strains generally have these structural genes, but are unable to build up a functional flagellum (Popoff et al., 1992). Early studies showed that Salmonella Pullorum and Salmonella Gallinarum have a cryptic structural gene, flagellin (Zinder \& Ledeberg, 1952). Several sequences of the gene encoding phase 1 flagellin (fliC) are available (Selander et al. 1992; Li et al., 1993; Kwon et al., 2000). The distal parts of the flic alleles are conserved regions, making this gene in any serotype suitable for easy amplification, whereas the central region of the flic gene is hyper variable, making it a target for differentiation among Salmonella serotypes (Wei \& Joys, 1985; Kilger \& Grimont, 1993; Dauga et al., 1998). Genetic events, such as point mutations, lateral transfer, and recombination, may explain the genetic diversity of Salmonella flagellin genes (Smith et al. 1990); Li et al., 1994) The SG and SP fliC gene represent allelic variants, and differ only in two codons (316 and 339) (Li et al., 1993). Kwon et al. (2000) showed that the Hinp1l enzyme recognizes one cleavage site in SG (codon 316), but not in SP.

The PCR-RFLP system has been frequently used in differentiation techniques because it is cheap and easy to perform. In our study, the fliC gene in SP (14 strains) and SG (22 strains), including intermediate strains dulcitol and ornithine descarboxylase positive and negative isolates in Brazil, were amplified. PCRamplicons (197bp) were digested with the Hinp1I enzyme. Two fragments were obtained $(82 \mathrm{bp}$ and $115 \mathrm{bp})$ for all SG strains, including one dulcitol and ornithine descarboxylase positive strain, whereas no digestion was observed in the 14 SP strains, which gene 
Paiva JB, Cavallini JS, Silva MD, Almeida MA, Ângela HL, Berchieri Junior A remained unchanged (197bp), including the two atypical strains.

The RFLP-PCR flagellar typing scheme was successfully applied to serotype identification in 112 Salmonella isolates obtained from poultry and poultry environment (Hong et al., 2003). Kilger \& Grimont (1993) showed practical application of restriction patterns of flic gene using a mixture of endonucleases (Taql and Scal) to differentiate Pullorum and Gallinarum strains from non-motile Salmonella Typhi and some flagellar strains of Salmonella; however, this method was not useful to differentiate Gallinarum from Pullorum strains. Kwon et al. (2000) demonstrated that fliC gene RFLP-PCR using Hinp 11 enzyme can be successfully applied for differentiate these two Salmonella serovars in Korean isolates. However, the authors tested only eight strains of each serovar, all presenting typical biochemical behavior. In the present study, we were able to demonstrate that the use of flic gene restriction patterns is an useful method to allow the differentiation between strains of $S$. Pullorum and S. Gallinarum isolated in Brazil, including those with atypical biochemical behavior. Therefore, our results reinforce that this method may be adopted to differentiate SP from SG.

\section{REFERENCES}

Barrow PA, Huggins MB, Lovell MA. Host specificity of Salmonella infection in chickens and mice is expressed in vivo primarily at the level of the reticuloendothelial system. Infection Immunology $1994 ; 62: 4062-4610$

Berchieri Jr. A, Freitas Neto OC. Salmoneloses aviárias. In: BERCHIERI Jr. et al. Doença das aves. 2.ed. Campinas: Facta; 2009. p.435451.

Boyd EE, Wang FS, Beltran P, Plock SA, Nelson K, Selander RK. Salmonella reference collection $B$ (SARB): strains of 37 serovars of subspecies. Journal of General Microbiology 1993; 139:11251132.

Christensen JP, Olsen JE, Hansen HC, Bisgaard M. Characterization of Salmonella enterica serotype gallinarum byotipes gallinarum pullorum by plasmid profiling and biochemical analysis. Avian Pathology 1992; 21:461-470.

Cox NA, Willians JE. A simplified biochemical system to screen Salmonella isolates from poultry for serotyping. Poultry Science 1976; 55:1968-1971.

Dauga CA, Zabrovscala A, Grimont PAD. Restriction fragment length polymorfism analysis of some flagellin genes of Salmonella enterica. Journal of Clinical Microbiology 1998; 36:2835-2843.
Molecular differentiation of Salmonella Gallinarum and Salmonella Pullorum by RFLP of fliC gene from Brazilian isolates

Ewing WH. Edwards and ewing's identification of enterobacteriaceae. 4th ed. New York: Elsevier Science Publishing; 1986. p. 81-318.

Grimont PAD, Weill F. Antigenic Formulae of the Salmonella serovars. 9th ed Paris: World Health Organization Collaborating Centre for Reference and Research on Salmonella, Institut Pasteur; 2007.

Hong Y, Liu T, Hofacre C, Maier M, White DG, Ayers S, Wang L, Maurer JJ. A restriction fragment length polymorphism-based polymerase chain reaction as an alternative to serotyping for identifying Salmonella serotypes. Avian Diseases 2003; 47:387395.

Kilger G, Grimont PAD. Differentiation of Salmonella phase 1 flagellar antigen types by restriction of the amplified flic gene. Journal of Clinical Microbiology 1993; 31:1108-1110.

Kisiela D, Kuczkowski M, Kiczak L, Wieliczko A, Ugorski M. Differentiation of Salmonella Gallinarum biovar Gallinarum from Salmonella Gallinarum biovar Pullorum by PCR-RFLP of the fimH gene. Journal of Veterinary Medicine 2005; 52:214-218.

Kwon JH, Park KY, Yoo HS, Park JY, Young HP, Kim SJ. Differentiation of Salmonella enteric serotype gallinarum byotipe pullorum from byotipe gallinarum by analysis of phase 1 flagellin $\mathrm{C}$ gene (fliC). Journal of Microbiological Methods 2000; 40: 33-38.

Li J, Nelson K, Mcwhorter AC, Whittam TS. Recombinational basis of serovars diversity in Salmonella enterica. Proceedings of the National Academy of Science 1994; 91:2552-2556.

Li J, Smith NH, Nelson K, Crichton PB, Old DC, Whittam TS, Selander RK. Evolutionary origin and radiation of the avian-adapted nonmotile Salmonellae. Journal of General Microbiology 1993; 38:129-139.

Olsen JE, Skov MN, Christensen JP, Bisgaard M. Genomic lineage of Salmonella enteric serotype Gallinarum. Journal of Medical Microbiology 1996; 45:413-418.

Pomeroy BS. Fowl typhoid. In: Hofstad, M.S. Barnes, H.J. Calneck, B.W., Reid, W.M., Yoder, H.W. Diseases of poultry. 8th ed. Ames: lowa State University Press; 1984. p.79-90.

Poppof MY, Le Minor L. Antigenic formulas of the Salmonella serovars, 7th rev. Paris: WHO Collaborating Centre for Reference and Research on Salmonella, Institut Pasteur; 1992.

Ribeiro SAM, Paiva JB, Zotesso F, Lemos MVF, Berchieri Jr A. Molecular differentiation between Salmonella enterica subsp enterica serovar Pullorum and Salmonella enterica subsp enterica serovar Gallinarum. Brazilian Journal Microbiology 2009; 40:184-188.

Selander RK, Smith NH, Beltran P, Ferris KE, Kopecko DJ, Rubin FA. Molecular evolutionary genetics of the cattle-adapted serovar Salmonella Dublin. Journal of Bacteriology 1992; 172:603-609.

Shivaprasad HL. Pullorum disease and fowl typhoid. Revue Scientifique et Technique de Office International des Epizooties 2000; 19:405-424 
Paiva JB, Cavallini JS, Silva MD, Almeida MA, Ângela HL, Berchieri Junior A
Molecular differentiation of Salmonella Gallinarum and Salmonella Pullorum by RFLP of flic gene from Brazilian isolates

Smith NH, Beltran P, Selander RK. Recombination of Salmonella phase 1 flagellin genes generates new serovars. Journal of Bacteriology 1990; 172:2209-2216.

Soumet C, Ermel G, Fach P, Colin P. Evaluation of different DNA extraction procedures for the detection of Salmonella from chicken products by polymerase chain reaction. Letters in Applied Microbiology 1994; 19:294-298.

Wei L, Joys TM. Covalent structure of three phase- 1 flagellar filament proteins of Salmonella. Journal of Molecular Biology 1985; 186:791-803.

Wray C, Davies Rh, Corkish JD. Enterobacteriaceae. In: Jordan FTW, Pattison, M. Poultry diseases. 4th ed. London: Saunders Company; 1996. p 9-43.

Zinder ND, Ledeberg J. Genetic exchange in Salmonella. Journal of Bacteriology 1952; 64:679-699. 
